\title{
Tritium leak at US reactor sparks crisis for neutron source users
}

[WASHINGTON] Brookhaven National Laboratory (BNL) on Long Island, New York, faces a year-long closure of one of its main research facilities - as well as a desperate battle to regain public confidence - after the discovery of major leaks of tritium in ground water near its High Flux Beam Reactor (HFBR).

The closure of the reactor has left hundreds of chemists, structural biologists, condensed-matter physicists and materials scientists scrambling for 'beam time' at other neutron sources in the United States and Europe, most already oversubscribed.

The leak is thought to have sprung from a 67,000 -gallon, concrete-lined canal used to cool and store spent fuel from the reactor. Senior officials from the Department of Energy travelled to the laboratory last week and assured the public that the facility will remain closed until the leak is dealt with.

Horizontal wells will be drilled to confirm the source of the leak. If it is the canal, the department will drain it, ship the spent fuel to Savannah River, South Carolina, for storage, and line the canal with stainless steel before restarting the reactor, which has been closed since December for routine refuelling. The process will take at least nine months, officials say.

Under pressure from local politicians including Senator Alfonse D'Amato (Republican, New York) and Congressman Michael Forbes (Republican, New York), the energy department has already issued a report on the incident which sharply criticizes BNL management for failing to respond to early requests from the county

\author{
IMAGE \\ UNAVAILABLE \\ FOR COPYRIGHT \\ REASONS
}

Closed for business: the High Flux Beam Reactor at the Brookhaven National Laboratory .

government to monitor ground water close to the reactor.

Some researchers fear that the tritium leak could damage the case for overdue upgrades at BNL and other existing sources. "We hope this doesn't cause any collateral damage" to the case for upgrades, one neutron scientist says.

Tara O'Toole, assistant secretary for environment, safety and health at the Department of Energy, travelled to Brookhaven last week to meet managers and to address an eight-hour public meeting in Riverhead, also attended by D'Amato and Forbes. O'Toole says that the restart "may take a little longer" than a year, adding: "I'd be surprised if it takes much longer."

But she warns that lack of public confidence could be "a major roadblock" to reopening the reactor, and calls on users inside and outside the laboratory to help to per-

\section{British peers want clearer research goals}

[LONDON] Britain's House of Lords has added its voice to those demanding a sharper focus to research activities funded through the European Commission in Brussels. It is seeking to have this expressed in plans now under discussion for the fifth Framework research programme (FP5), due to run from 1998 to 2001 (see Nature 385, 665; 1997).

In a report to be published in London today (6 March), the Lords science and technology committee says it is "astonished" at the breadth of the commission's current proposals for FP5. "We had been expecting the commission to come up with proposals that were much better focused than what has appeared so far," says Lord Selborne, the chairman of the Lords committee.

On the basis of a series of hearings held over the past few months, which included witnesses from both Brussels and the British research community, the committee says it is unimpressed by the direct outcomes of research money spent through the commission. It suggests that similar results could have been achieved by spending the same amounts at national or global level.

Meanwhile, the commission has published a response to recent criticism. It says that the need to ensure that a five-year programme corresponds to the desires both researchers and "the people of Europe" means that its approval is inevitably a lengthy procedure, and insists that with a reduced number of planned programmes, "the new management structure will be lighter and more flexible". [SEE ALSO page 5 ] suade the public that the reactor is needed for research. "To some extent, it is in their hands," she says. "They have to take responsibility for educating the community" as well as listening to its concerns "in a respectful manner".

Brookhaven has sunk 500 wells since 1989 to monitor ground water, chiefly at the boundary of its site. But last August two wells were sunk near the HFBR, and abnormal levels of tritium found in them in December.

More test wells and sampling confirmed tritium at levels of up to 50,000 picocuries per litre by mid-January, when the laboratory announced the problem. Further sampling at the beginning of February showed levels as high as 651,000 picocuries per litre - 30 times the drinking-water limit set by the Environmental Protection Agency.

Samples collected so far suggest that the tritium is distributed underground in a plume 1,000 feet long and 100 feet in diameter. It is probably moving at less than a foot a day, according to Henry Bokuniewicz of Long Island Groundwater Institute at the State University of New York.

"The risk to water supplies is nonexistent at this stage," he says, adding that the tritium - which has a half-life of 12 years should decay before it reaches the local water supply wells four miles away.

Bob Casey, head of safety and environmental protection at Brookhaven, says that, although the need for a groundwater monitoring well was identified in 1994, it was not dug because there was no particular reason to give it priority.

The decision might have been different, Casey says, if he had known that the canal was liable to leaks. According to 1963 design calculations unearthed in the energy department's new report, its permeable concrete walls are liable to leak " 3 to 8 gallons a day".

BNL officials now fear that their recent 